Chirurgia (2018) 113: 123-136

No. 1, January - February

Copyright $\odot$ Celsius

http://dx.doi.org/10.21614/chirurgia.113.1.123

\title{
Cervical Exenteration - Guidelines and Surgical Technique Principles
}

\author{
Constantin Ciuce', Răzvan Scurtu', Cătălin Ciuce', Raluca Apostu', Horea Bocșe ${ }^{2}$, George Dindelegan ${ }^{1}$ \\ ${ }^{1}$ Surgical Clinic I, "Iuliu Hațieganu” University of Medicine and Pharmacy, Cluj-Napoca, Romania \\ 2“Iuliu Hațieganu" University of Medicine and Pharmacy, Cluj-Napoca, Romania
}

Corresponding author:

Răzvan Scurtu, MD

Surgical Clinic I, "Iuliu Hațieganu"

University of Medicine and

Pharmacy, Cluj-Napoca, Romania

.3-5, Clinicilor street, 400006

Cluj-Napoca, Romania

E-mail: rrscurtu@yahoo.com
Received: 04.01.2018

Accepted: 06.02.2018

\section{Rezumat}

Exenterația cervicală - Indicații și principii de tehnică chirurgicală

Introducere: Invazia neoplazică a structurilor regiunii cervicale având ca origine o tumoră malignă dezvoltată în unul dintre viscerele gâtului poate beneficia de exenterație cervicală. Definită ca rezecție a hipofaringelui, esofagului cervical, laringelui şi a traheei cervicale, exenterația are indicații limitate şi este obligatoriu însoțită de reconstrucția tubului digestiv. Scopul acestui articol este de a evidenția indicația, strategia operatorie şi timpii chirurgicali importanți ilustrați cu imagini din experiența personală.

Metoda: Rezecția în bloc faringolaringoesofagiană şi limfadenectomia radicală cervicală au fost urmate de reconstrucție prin transfer liber de jejun sau cu grefon colic pediculat. In intervalul 2000-2018 am efectuat exenterație cervicală la 25 de pacienți pentru tumori cu punct de plecare în faringe, laringe sau esofagul cervical. În cazul a 5 pacienți la care nu am obținut limita de siguranță oncologică a cancerului esogfagian, am efectuat faringolaringoesofagectomie transhiatală. Pentru aceşti pacienți am reconstruit esofagul cu grefon colic. În 20 de cazuri am efectuat autotransplant de jejun.

Rezultate: Am avut 4 decese perioperatorii, prin hemoragie din vase arteriale majore ( 1 caz), după necroza de jejun (2 cazuri) şi mediastinita după striping esofagian şi necroza de grefon colic ( 1 caz). Un pacient a prezentat recidiva tumorală pe bontul traheal. Supraviețuirea a oscilat între 6 luni şi 4 ani pentru grupul de pacienți care s-au prezentat la controalele postoperatorii.

Concluzii: Exenterația cervicală rămâne ca opțiune pentru recidivele tumorale după radiochimioterapie sau pentru tumorile obstructive ale căii aeriene sau digestive. Poate fi grevată de complicații dificil de tratat. Echipa chirurgicală trebuie să-şi adapteze strategia 
operatorie inițială la realitatea câmpului operator atât în ceea ce priveşte exereza, cât şi modalitățile de reconstrucție faringoesofagiană.

Cuvinte cheie: exenterație cervicală, transfer liber jejun, carcinom scuamos esofagian

\begin{abstract}
Introduction: Neoplastic invasion of the structures of the cervical region originating from a malignant tumour developed in one of the viscera of the throat may benefit from cervical exenteration. Defined as resection of the hypopharynx, cervical oesophagus, larynx and cervical trachea, exenteration has limited indications and is mandatorily accompanied by digestive tube reconstruction. The aim of this article is to highlight the indication, surgical strategy and important surgical stages illustrated by images from personal professional experience.

Materials and method: Pharyngo-laryngo-oesophageal en bloc resection and radical cervical lymphadenectomy were followed by reconstruction via free jejunal transfer or colic pedicle grafting. Between 2000 and 2018 we have performed cervical exenteration in 25 patients with tumours originating in the pharynx, larynx or cervical oesophagus. In the cases of 5 patients in whom we did not obtain the oncological safety margin for oesophageal cancer we performed transhiatal pharyngo-laryngo-oesophagectomy. In these patients, we performed reconstruction of the oesophagus with colonic graft. In 20 cases we performed jejunal autotransplant.

Results: We recorded 4 perioperative deaths, due to major arterial vessel haemorrhage (1 case), after jejunal necrosis (2 cases), and mediastinitis after oesophageal striping and colonic graft necrosis (1 case). One patient presented tumour recurrence at the level of the tracheal stump. Survival rate varied between 6 months and 4 years for the group of patients who presented for postoperative follow-ups.

Conclusions: Cervical exenteration remains an option for tumour recurrence after radiochemotherapy or for obstructive airway or digestive tract tumours. It can be burdened by complications difficult to treat. The surgical team has to adapt its initial surgical strategy to the reality of the surgical field, both in terms of exeresis and in terms of types of pharyngo-oesophageal reconstruction.
\end{abstract}

Key words: cervical exenteration, free jejunal transfer, esophageal scuamous carcinoma

\section{Introduction}

Cervical exenteration involves en bloc resection of the cervical viscera - larynx, pharynx, cervical oesophagus, partial resection of the trachea, thyroid gland and parathyroid glands. It is accompanied by cervical lymphadenectomy, definitive tracheostomy, and followed by pharyngo-oesophageal reconstruction via microsurgical free transfer - jejunum, fasciocutaneous flaps - or pedicle transfer - stomach or colon $(1,2)$.

Cervical exenteration has limited indications. It addresses malignant tumours of the cervical area viscera, locally advanced, with partial response to chemoradiotherapy, or tumours developed as local recurrences after radiochemotherapy, determining tight stenoses or obstructions along the digestive and/or airway tract, accompanied or not by destruction of the soft areas of the anterior cervical region, but without metastases at a distance, with the objective of local control.

If the soft tissues of the anterior cervical region are infiltrated by tumour cells or destroyed through radiation, they should be removed from the healthy tissue.

If the tumour process includes the large 
vessels of the neck, the decision is made depending on the vessels involved.

Extension of the tumour process to the prevertebral fascia contraindicates cervical exenteration.

Oftentimes development of the neoplastic process in the cervical region, coupled with tissue reaction to irradiation, sets the surgical team face to face with a patient with a "frozen" neck, complicating the decision and the surgical strategy.

Cervical exenteration and the reconstruction of secondary defects involve a high degree of complexity and the risk of corresponding complications.

\section{Materials and Method}

Patients meeting the criteria for surgical indication are evaluated preoperatively.

Nutritional status, tumour extension to the skin, local changes induced by irradiation, the presence of adenopathies are evaluated from a clinical point of view.

Laboratory results provide us with data regarding the patient's biological condition.

Cardiac and respiratory function, as well as possible comorbidities are also assessed.

If the tumour is not completely obstructive, the ENT examination and oesophagoscopy can re-evaluate the extension of the tumour in order to obtain information concerning the cervical or superior thoracic oesophagus. If there is reason to suspect the presence of subtumoral extension, biopsy of the suspected area is performed.

If the cancer extends to the upper thoracic oesophagus, bronchoscopic assessment associated or not with ultrasound exam is required to identify a possible invasion of the trachea and/or bronchi.

Ultrasound can provide data on adenopathies in the cervical region. Lymph node invasion can be certified by fine-needle aspiration biopsy.

Contrast CT may provide additional information regarding the cervical region. PET or PET/CT scans are useful in assessing the chest and abdomen in order to highlight possible metastases at a distance.
When there is suspicion of vascular invasion of the carotid arteries or jugular veins, an angio-CT scan or angiography can provide information on its extension and regarding the permeability of the circle of Willis.

Invasion of the cervical prevertebral fascia or detection of metastases at a distance contraindicate cervical exenteration. In these cases, if the patient is not already tracheotomised, tracheostomy and gastrostomy /jejunostomy are performed for palliative purposes.

\section{Surgical Technique Principles}

The surgical strategy should be adapted to each patient individually, according to the results of the preoperative investigations, but especially to the surprises recorded intraoperatively.

The surgical team must be prepared for visceral, vascular and soft tissue resections and reconstructions, including free tissue transfers through microsurgery techniques.

\section{Patient Position and Preparation of the Surgical Field}

The patient will be positioned in dorsal decubitus, with the head in mild hyperextension if possible. The placement of electrodes and venous and arterial access lines will be performed remotely from the surgical field.

The surgical field will be broad, with a cranial limit represented by the protuberantia mentalis and the mastoid apophyses, a distal limit represented by the pubis, and bilateral limits represented by the supraclavicular fossae and the medium axillary line, exposing the cervical region, thorax and abdomen within the aforementioned limits.

If, based on preoperative imaging or clinical assessment, use of vascular grafts or free split-thickness skin grafting appears to be required, the surgical field will also include a lower member as the donor source.

\section{Strategy and Surgical Stages}

Strategy and surgical stages will be chosen and adapted according to the patient and intraoperative re-evaluations. 


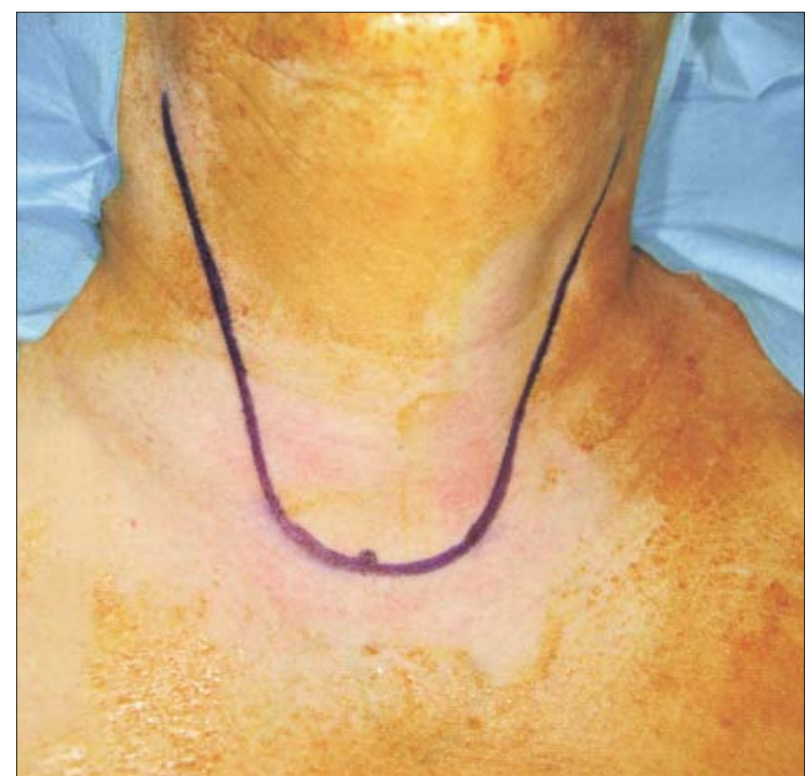

Figure 1. Cervical skin flap

- The incision is performed in the form of the letter "U", with its opening oriented towards the cranial pole, along the anterior edges of the sternocleidomastoid muscles up to the mandibular angle and are joined together at the inferior pole through an incision at the level of the upper edge of the sternal manubrium (Fig. 1).

- If the soft tissues are free of disease, the proximal flap is detached and attached to the protuberantia mentalis (Fig. 2). If the skin presents tumour invasion or deep changes due to irradiation, it will usually be excised en bloc with the tumour process.

- Assessment of resection extent possibility represents the first stage. For this purpose, the medial side of the sternocleidomastoid muscle is accessed, medial to the cervical neurovascular bundle and evaluation concerning whether the tumour respects the prevertebral fascia limits is performed (Fig. 3). This evaluation is difficult in the case of "frozen" neck, where the vascular pedicle - carotid artery and internal jugular vein - must be dissected beforehand.

If the prevertebral fascia is invaded, exeresis

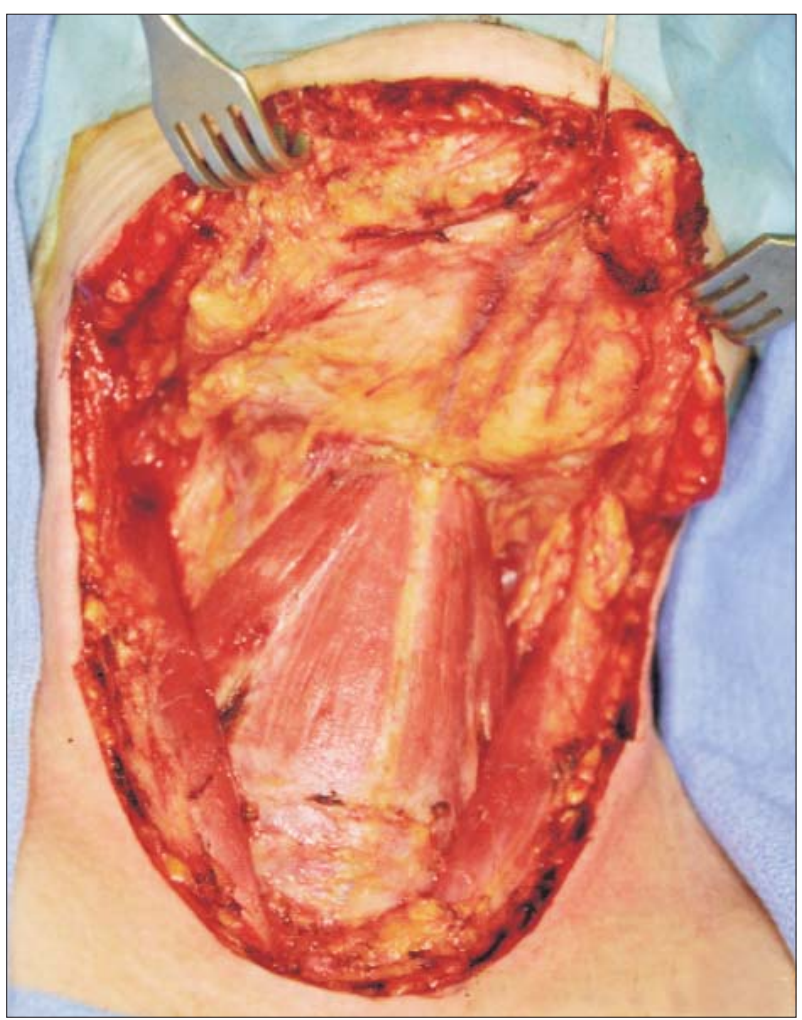

Figure 2. The cervical flap is detached and attached to the protuberantia mentalis and the inferior edge of the mandible

surgery is abandoned and tracheostomy is performed (if it has not already been performed) and a gastrostomy tube is set in place via classical surgery approach for tumours associated with tight or obstructive stenosis.

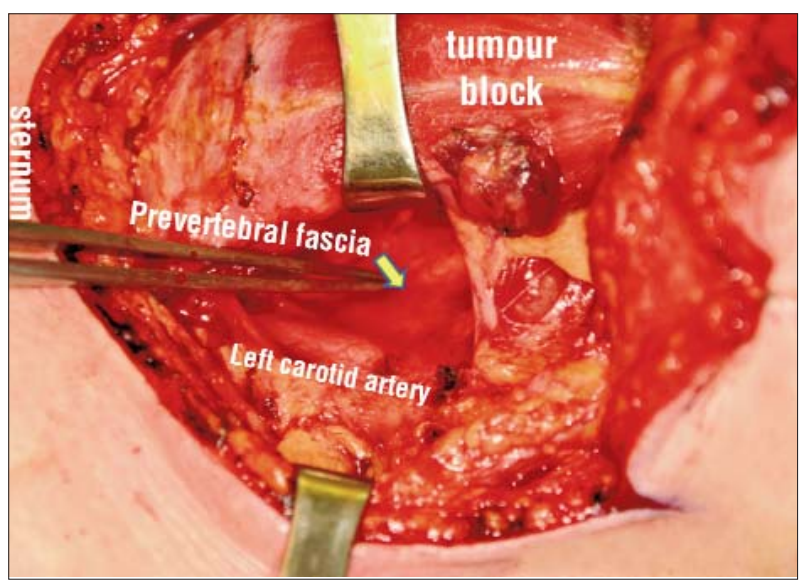

Figure 3. Detachment of the oesophagus from the prevertebral fascia, medial to the left carotid artery, to confirm resectability 
- Isolation of carotid arteries and internal jugular veins, bilaterally, continues the exploration stage for resection. This isolation can cause vascular damage that is difficult to manage in tumours invading vascular bundles, especially in the case of "frozen" neck. In these situations it is preferable that the carotid arteries and jugular veins be isolated on strands inferior to the tumour process that includes them. Sometimes it is necessary to resect the sternoclavicular joint for a safe vascular approach.If a jugular vein is included in the tumour process, it is ligaturated proximal and distal to the tumour and is excised en bloc with the tumour. If both jugular veins are invaded by the tumour process, the authors prefer to reconstruct one of them with a synthetic or venous graft from the internal saphenous vein, which is sectioned longitudinally and sutured in a spiral to obtain a suitable lumen calibre for the internal jugular vein.

If the common carotid artery, embedded in the tumour, can be subadventitially dissected from the tumour process, even if it is thinned, but with present flux, we conserve it. If the carotid artery is embedded in the tumour, but the contralateral common carotid artery is unaffected, the circle of Willis is permeable, and the carotid artery bifurcation can be isolated, the common carotid artery is clamped under the bifurcation, sutured, and excised en bloc with the tumour, keeping the bifurcation intact and not reconstructing it.

- If the thyroid is not affected by the tumour, a lobe is isolated together with the parathyroid gland on the upper thyroid pedicle. In the case of oncological uncertainty, the thyroid is excised en bloc with the tumour.

- The trachea and cervical oesophagus (Fig. 4) are isolated and cervical pharyngolaryngo-oesophagectomy is performed, with en bloc resection of the tumour (Fig. 5). If the patient was not submitted to tracheostomy prior to surgery, the anterior wall of the trachea is fixed to the

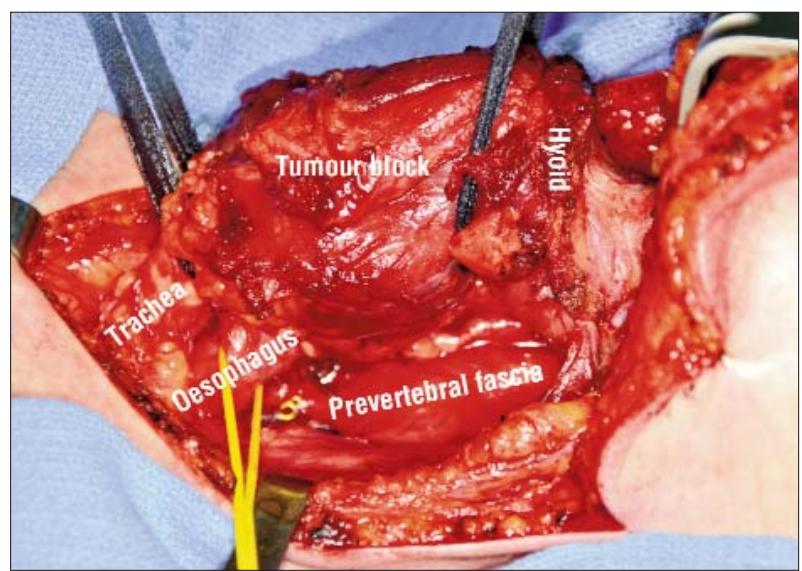

Figure 4.

suprasternal notch tegument and the anaesthesia machine is connected to the tracheostomy cannula introduced intraoperatively into the trachea.

- Extemporaneous anatomopathological exam of the resected margins of the pharynx, oesophagus and trachea, which will decide the following surgical steps.

- Until the extemporaneous anatomopathological results are obtained, modified radical dissection of the neck is performed and the recipient vessels are prepared for reconstruction by free transfer of tissues (Fig. 6).

- If at extemporaneous examination the section piece is invaded towards the pharynx, oesophagus or trachea, circumferential re-excision is performed and the piece is submitted for a new anatomopathological extemporaneous examination (Fig. 7).

- If at extemporaneous re-examination of the proximal section piece there is tumour infiltration, resection is repeated until the oncological safety margin is obtained.

- If the tracheal stump is infiltrated with tumour cells at extemporaneous anatomopathological examination, the incision is prolonged towards the inferior pole and the sternal manubrium is excised together with the sternoclavicular joints and the first two chondrocostal cartilages, transforming the cervical tracheostomy into mediastinal tracheostomy. Since this work 

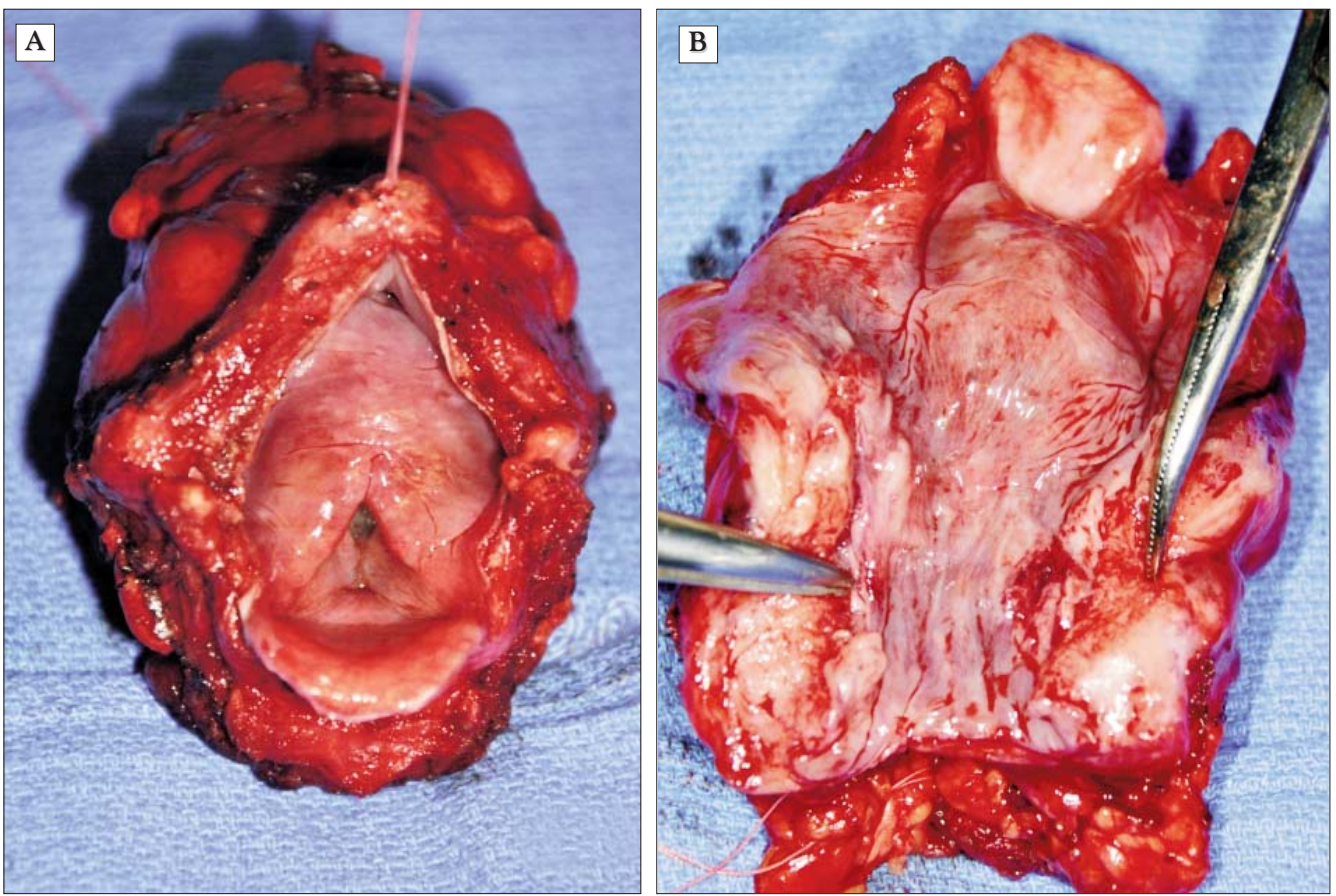

Figure 5. Pharyngo-laryngo-oesophageal resection piece. Cvasi-complete cervical oesophageal stenosis can be observed (A). On the piece visible through the section of the posterior pharyngo-oesophageal wall (B), tumour infiltration of the cervical oesophagus with distal resection margin, probably insufficient at the distal pole, is observed

may involve the sectioning of the unnamed artery to avoid its erosion by the tracheal stump, with secondary cataclysmic haemorrhage, we must take into account the integrity of the cervical arterial vessels to ensure that the blood supply to the brain is correct.

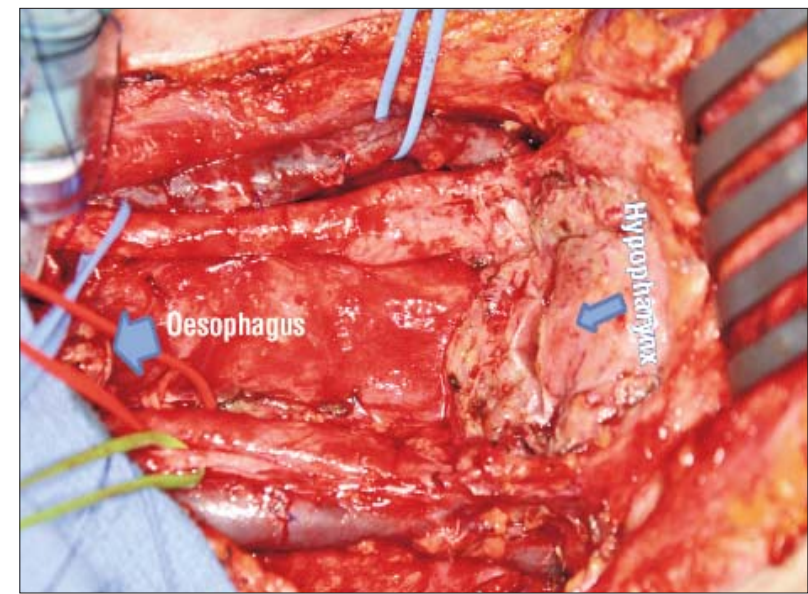

Figure 6. The cervical region after tumour block removal and radical cervical lymphadenectomy
- If the cervical tracheal stump is free of malignant cells at extemporaneous examination, but the oesophageal stump is still infiltrated by the tumour after repeated resection, the surgical strategy may involve two attitudes:

a. the cervical incision is extended on the

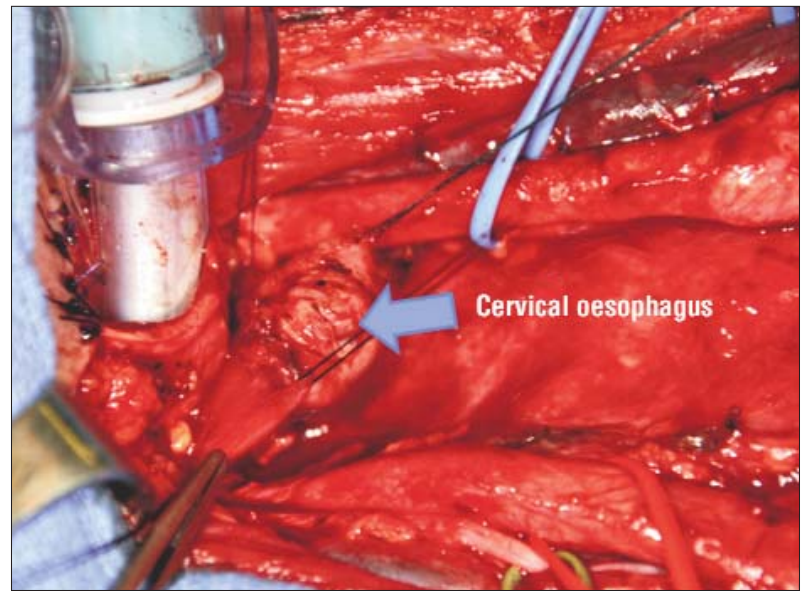

Figure 7. $2 \mathrm{~cm}$ were re-resected at the level of the cervical oesophagus for the tumour infiltrated section piece 
median line from the supraclavicular notch to the upper third of the thorax and the left sternoclavicular joint is removed with the first two chondrocostal cartilages. The superior thoracic oesophagus is dissected and resected again. If no tumour cells are detected at extemporaneous anatomopathological exam at the level of the oesophageal stump, reconstruction by the free jejunal transfer is continued. If the oesophageal stump presents tumour infiltration, transhiatal oesophagectomy and reconstruction by colonic grafting are performed.

b. reconstruction of the pharynx and of the cervical oesophagus by free jejunal transfer is abandoned and transhiataloesophagectomy is performed, followed by reconstruction with colonic graft.

After the resection is completed, the remaining defect is evaluated after cervical exenteration associated or not with transhiataloesophagectomy and/or skin flap resection of the anterior region of the neck.

\section{Reconstruction after Cervical Exenteration}

Considering the aforementioned vascular arterial and venous implications, resolved by resections or grafts, the following defects of the cervical region requiring reconstruction can be encountered:

1. Pharynx and cervical oesophagus defect with whole cover cervical skin flap. Reconstruction can be performed by free transfer of tissues - fasciocutaneous flaps or jejunum. We prefer to use jejunal autotransplant.

2. Pharynx and cervical oesophagus defect, with absent cervical skin flap by deliberate excision. Pharyngo-oesophageal reconstruction with jejunum tissue requires a second, concurrent free transfer, as a coating for the jejunal autotransplant. It may be a fasciocutaneous flap or the epiploon covered by a free split-thickness skin graft. Personally, I use the epiploon, in one case having covered the transplanted jejunum with mesenteric tissue, in deliberately excessive quantity, and covered by a free split-thickness skin graft.

3. Pharyngeal and oesophageal defect after transhiatal pharyngo-laryngo-oesophagectomy. For reconstruction we use left colonic graft with isoperistaltic interposition.

Reconstruction after cervical exhaustion by free tissue transfer involves the selection of the recipient vessels and of the tissues involved in reconstruction:

As recipient vessels for tissue autotransplants I choose the common carotid artery and the internal jugular vein. If a second free transfer for coverage of the transplanted jejunum is required, I choose the upper thyroid artery and the external jugular vein as recipient vessels, usually on the same part of the anastomoses performed for the revascularization of the jejunum. Of course, depending on the particularities of the case, resulting from the extension of the cervical exenteration, good quality recipient vessels must be identified. In the extreme, if there is a lack thereof, one can resort to an internal saphenous vein graft.

For the reconstruction of the pharynx and the cervical oesophagus we use a jejunum graft. The graft is harvested by median laparotomy, isolating a segment of the jejunum suitable in length for the cervical defect, about $30-40 \mathrm{~cm}$ from the duodenojejunal angle.

Transillumination (Fig. 8) identifies a good

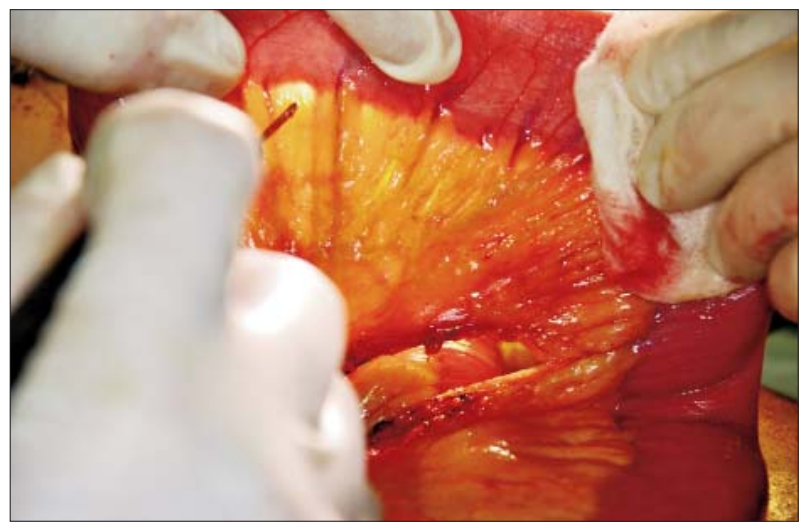

Figure 8. Isolation of the jejunum for cervical reconstruction. The incision of the mesentery between the right vessels is facilitated by transillumination 
quality jejunal vascular bundle, usually the second or third artery and jejunal vein. The vascular pedicle of the chosen jejunal segment is dissected, closing in on the origin of the artery on the main trunk of the superior mesenteric artery, more precisely the flowing of the jejunal vein into the upper mesenteric vein. It is loaded onto vascular strings. The collaterals at the level of the mesenteric arches are dissected, ligatured and sectioned, on both sides of the chosen pedicle, up to the mesostenic edge of the jejunum. Hematomas at the level of the mesenteric segment isolated for free transfer should be avoided. In order to reduce the curvature and facilitate the rectilinear positioning at cervical level of the jejunal segment isolated on the vascular pedicle, small incisions between the marginal arch and the mesostenic edge thereof are performed, parallel to the straight vessels.

The chosen jejunal loop is completely isolated on its vascular pedicle by sectioning of the jejunum on one side and the other of the mesenteric section. A marker wire is placed at the cranial pole of the graft for correct, isoperistaltical positioning in the cervical region (Fig. 9). The intestinal continuity is restored by the end-to-end anastomosis.

The jejunal segment is detached through ligature of the vascular pedicle (Fig. 10) - initially the artery and then the jejunal vein - and is isoperistaltically transposed into the cervical region. While another team closes the mesenteric breach, sets a feeding jejunostoma in place and closes the laparotomy wound, (Fig. 11) the anaesthesiology team monitors the ischemic time of the intestinal graft. It is preferable that it does not exceed two hours. The team responsible for the cervical region interposes the jejunal graft between the pharynx and the cervical oesophagus stump. We begin with oesojejunal anastomosis performed manually or mechanically. If we use a mechanical clamp, it will be inserted into the jejunum while it is in the abdomen, before the vascular pedicle is sectioned, in order to reduce the ischemia time.

For pharyngo-oesophageal anastomosis we can use the end-to-side or end-to-end variants, in which case we reduce the pharyngeal calibre by applying suture threads to the transverse section

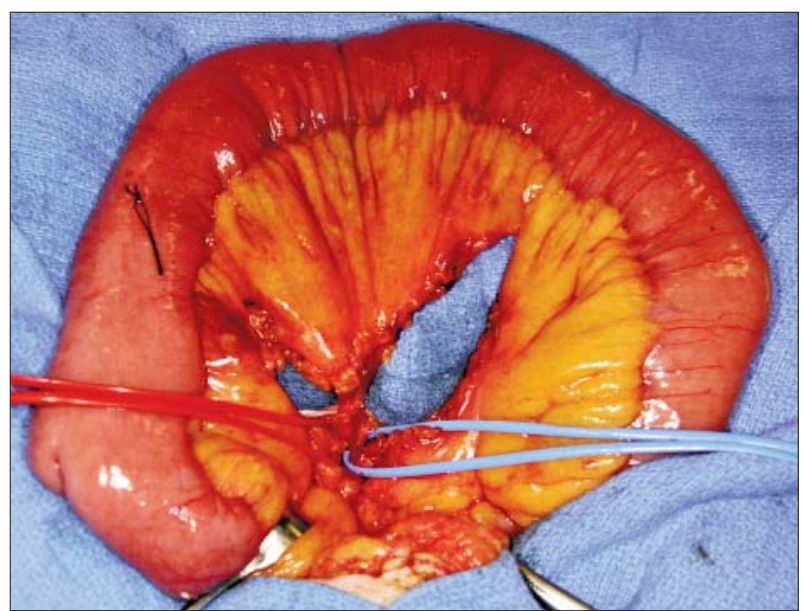

Figure 9. The jejunal vessels serving the jejunum segment for autotransplantation are isolated on the strand. A wire marks the end of the jejunum extremity at the duodenal junction angle

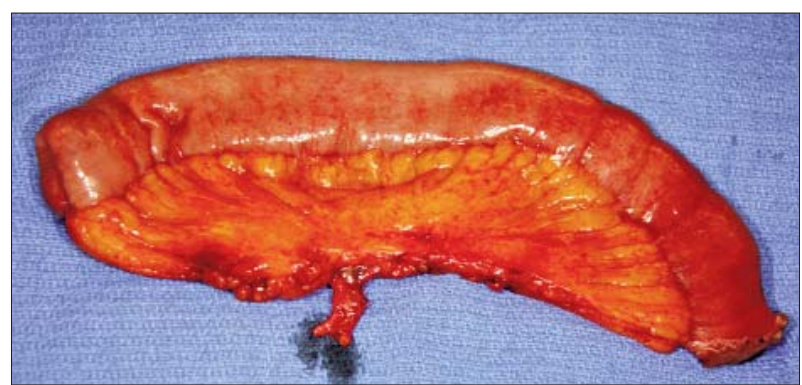

Figure 10. Jejunum segment with closed proximal extremity for an end-to-end pharyngo-jejunal anastomosis and sectioned jejunal vessels

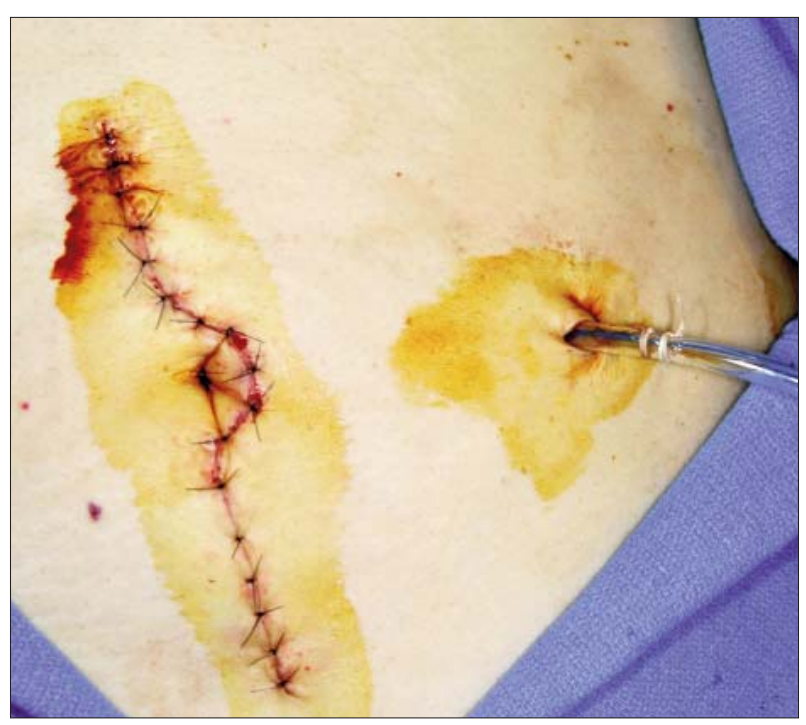

Figure 11. Jejunostomy probe and laparoraphy 


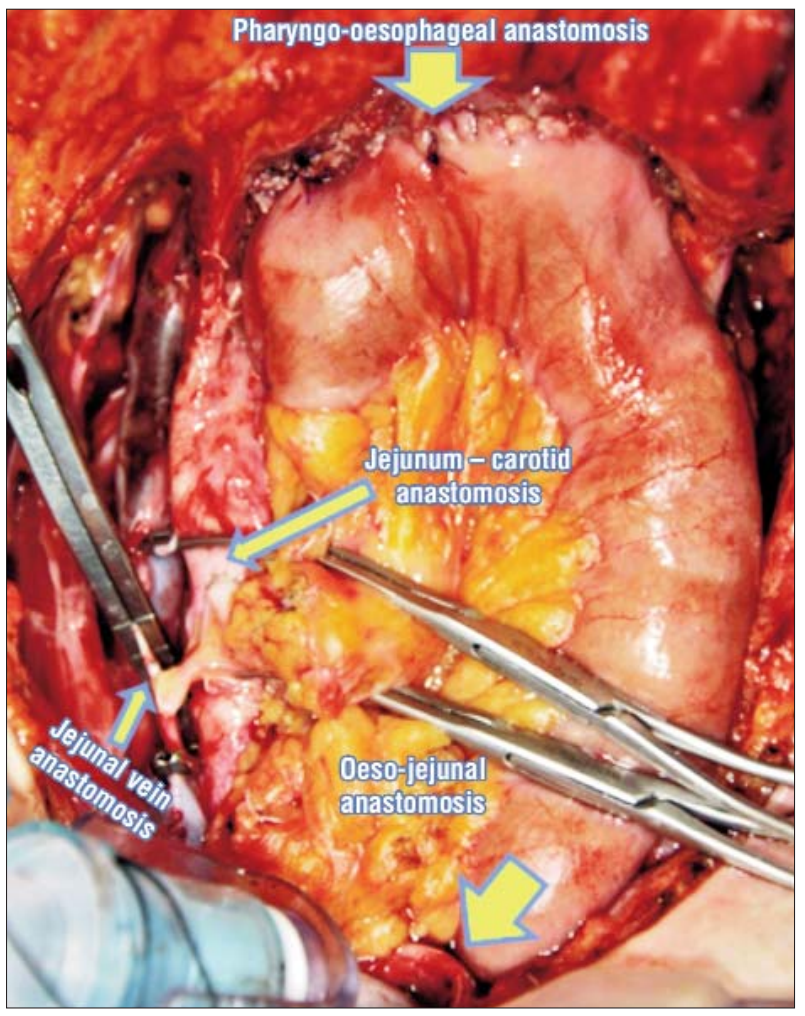

Figure 12. Finalized end-to-side pharyngo-oesophageal and end-to-end oeso-jejunal anastomoses. Finalized end-to-side anastomosis between the jejunal artery and the carotid artery, but flow through the carotid artery is stopped by vascular clamps. End-to-side anastomosis between the jejunal vein and the jugular vein is finalized. The intestine is not vascularized

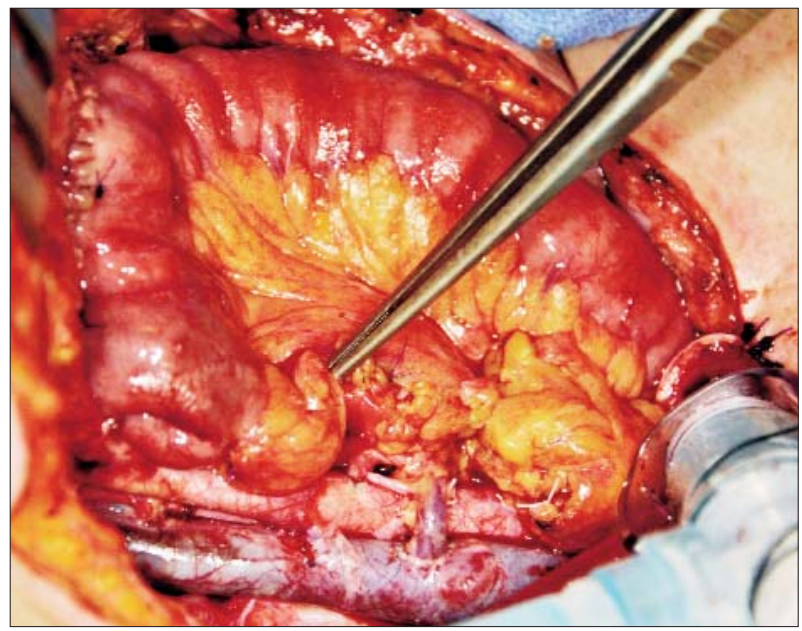

Figure 13. Revascularized jejunum

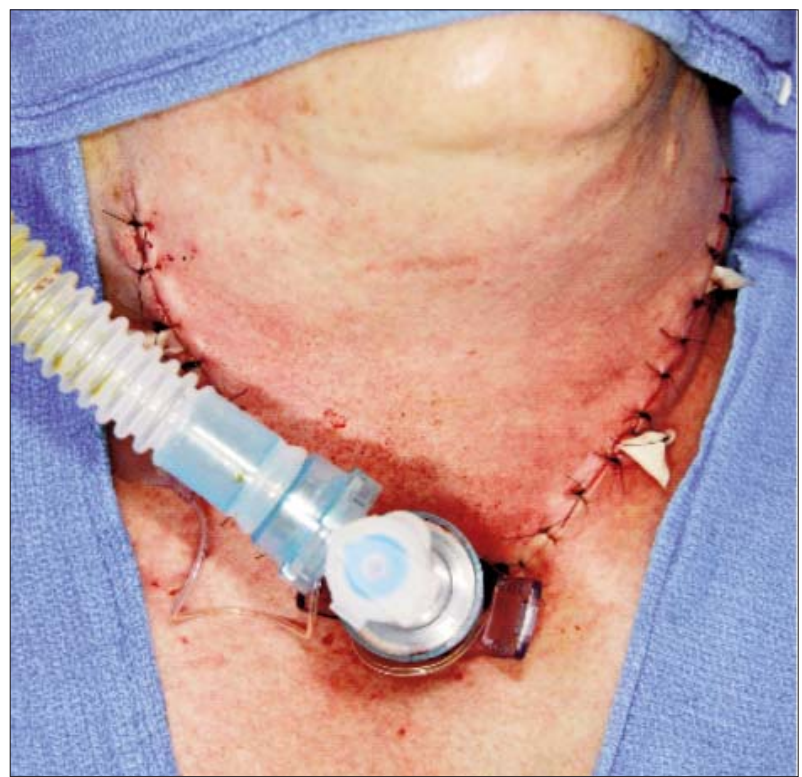

Figure 14. Cervical flap covering the free jejunal transplant

jejunal segment, we isolate an epiploic mesh on the right gastroepiploic pedicle, sectioning the vessels between the epiploon and the stomach, between ligatures. We ensure that haemostasis of the vessels of the epiploon is correctly performed. We isolate the epiploic mesh in a compress with warm saline fluid and continue to isolate the jejunal segment after the aforementioned surgical stages.

After we ensure that the free transfer of the jejunum is functional, we section the right gastroepiploic pedicle and transfer it to the 
cervical region. Then we proceed to revascularize it through microvascular anastomoses to the recipient vessels of the region.

We cover the jejunum with epiploon tissue and fill the spaces resulting from exenteration and radical dissection of the neck. We then cover the epiploon with a split-thickness skin graft.

For reconstruction after cervical exenteration and transhiatal oesophagectomy I use the left colic graft, transported isoperistaltically through the posterior mediastinum.

As the colonic graft is long, in order to reduce the risk of vascular compromise of the ascending cervical end, I isolate it on the left ileocolic artery and vein, keep the marginal arch intact in the distal section region of the colic graft, maintain the bifurcation of the middle colic vessels intact, and, if the Riolan arch is deficient, incorporate part of the ascending branch of the right colic pedicle in the graft.

Pharyngo-oesophageal anastomosis is followed by gastro-colic and colo-colic anastomosis.

If the colic graft shows signs of arterial insufficiency or is congestive due to venous return deficiency, I perform anastomosis with the cervical recipient vessels, as the case may be, the ascending branch of the right colic pedicle, arterial, venous or both. This way, the colonic graft is vascularized through the abdominal pedicle and receives / drains the blood for the cervical portion through vascular anastomoses with cervical recipient vessels.

If the skin flap in the cervical region is inexistent, I use a pedicle epiploon flap on the right gastro-epiploic pedicle to cover the colic graft, transported together with the colon via the posterior mediastinum and exteriorized in the cervical region, anterior to the colon. If the epiploon is too large and risks compressing the colonic graft in the posterior mediastinum, there are two alternatives. Either a free epiploon transfer is performed according to the described technique, or a pre- or retrosternal tunnel is created to transport the isolated epiploon in the cervical region on the right gastroepiploic pedicle. Over the epiploon exteriorized in the cervical region, covering the colonic graft, a split-thickness skin graft is applied.

\section{Postoperative care}

It addresses the prevention of vascular anastomosis thrombosis, tracheostomy, and the correction of ionic metabolism disorders.

Prevention of vascular anastomosis thrombosis. We administer small molecule heparin in prophylactic doses postoperatively. The dose may be increased if the anastomoses were performed on a carotid artery that is either atherosclerotic, or modified by irradiation. Careful haemostasis even at the level of small vessels prevents the risk of developing a hematoma that can become compressive and compromise autotransplantation through vascular anastomosis thrombosis.

External compression can also occur due to the thread that fixes the tracheostomy probe or the compression bandages / dressings.

Tracheostomy - should be carefully monitored and cared for, especially in patients in whom the free jejunum transfer was covered with epiploon.

Hydric, acid-base, and ionic balance are controlled, especially in patients in whom the parathyroid glands could not be conserved, and a body temperature that favours vasodilation should be maintained. Feeding is ensured via the jejunal probe. The abdomen is monitored and abdominal transit is resumed. On the 9th postoperative day (with variations between 7-14 days) the status of the digestive anastomoses is assessed by radiological evaluation (Gastrografin) and oral nutrition is restored. If the patient was preoperatively irradiated and/or the nutritional status was precarious, we tend to keep the jejunal probe in place up to $3-4$ weeks after surgery. If clinically or radiologically there are signs of a low-debit fistula that does not force reintervention, we continue feeding via the jejunal probe until the fistula is healed, with radiological confirmation.

\section{Complications}

After exenteration surgery and cervical reconstruction with autotransplanted jejunum, general complications characteristic of large surgical operations of this type can occur (cardiac, pulmonary, etc.), and specific complications 
respectively, at the level of the harvest area (abdomen) or at cervical level.

- Abdominal complications are very rare: hematoma at the base of the mesenteric area corresponding to the harvested jejunal segment, internal hernia through mesenteric breach, fistulas at the level of the entero-enteral anastomosis. These can be prevented through a careful surgical technique.

Cervical complications:

- Necrosis of the jejunal graft may occur in $3-20 \%$ of cases. This is due to either thrombosis of anastomoses by general or local intravascular factors, or to extrinsic compression - hematoma, compression bandage or the strip that fixes the tracheostomy cannula if it is too tight. It is usually not diagnosed in time for revascularization. The necrotic tissue is removed concurrently with digestive reconstruction, resorting to a new jejunum autotransplant if the necrosis is not accompanied by infection.

- Pharyngo-jejunal or jejuno-oesophageal anastomotic fistulae occur in $15-20 \%$ of cases. They usually present with low debit and are treated conservatively by suppressing oral nutrition, enteral nutrition via the jejunostoma, and local cleaning. Fistulae resulting from necrosis of the graft used for oesophagoplasty require necrectomy and reconstruction. Anastomotic stenoses are more rare, usually occurring after anastomotic fistulae, and are resolved by dilation via endoscopy.

- Vascular complications arising from the restoration of the main arterial and/or venous trunks are represented by haemorrhage or thrombosis. Haemorrhage usually occurs at the level of the micro-macrovascular anastomosis area and requires reintervention and haemostasis. If thrombosis occurs on the internal jugular vein and the contralateral jugular vein is unaffected, venous drainage of the head is not affected, but if thrombosis blocks the venous drainage of the jejunal graft it compromises its viability.
- The tracheostomy may present skin dehiscence requiring local treatment. In the case of mediastinal tracheostomy, dehiscence of the tracheal stump can cause mediastinitis with severe sepsis or erosion of mediastinal vessels with cataclysmic haemorrhage. A pedicle epiploic flap interposed between the trachea and the unnamed artery would prevent possible haemorrhages in the case of mediastinal tracheostomies.

- Injury of the thoracic duct may be responsible for extravasation of the lymph into the surgical wound that may require wound re-exploration or even thoracotomy for suture or ligature of the thoracic duct. Currently, radiological methods of percutaneous embolization have become more effective, allowing obstruction of the thoracic duct by stopping lymphorrhagia in a much less aggressive manner (3).

\section{Clinical Experience}

We performed cervical exenteration in 25 patients during a period between 2000-2018 for invasive larynx tumours or hypopharynx tumours extended in the cervical oesophagus. Five patients presented with "frozen" neck after irradiation with partial tumour remission. The tumour encompassed the common carotid artery, unilaterally in 3 cases, and required resection proximal to the bifurcation in one case. The internal jugular vein was embedded in the tumour unilaterally in 3 cases and bilaterally in one case. In the case of bilateral invasion, the less affected vein was reconstructed with synthetic prosthesis, and the anastomosis of the jejunal graft was performed under distal anastomosis on the internal jugular vein.

To obtain tumour free margins on the cervical oesophagus stump, we dissected the left sternoclavicular joint in six patients and reresected the oesophagus to the level of healthy tissue. In the case of 5 patients, we performed transhiatal pharyngo-laryngo-oesophagectomy for submucosal extension of the squamous cell carcinoma. We reconstructed the oesophagus with colonic graft in 5 cases and with jejunum 
autotransplant in 20 cases. In two patients with major soft tissue defect we performed a double free transfer of the jejunum and epiploon. In one case, the soft tissue defect was covered with the mesentery of the jejunum transplanted into the cervical area, deliberately harvested in excess. One patient developed tumour recurrence on the tracheal stump. We recorded 4 perioperative deaths: by major arterial haemorrhage (1 case), after jejunum necrosis ( 2 cases), and through mediastinitis after oesophageal striping and colonic graft necrosis (1 case). Survival oscillated between 6 months and 4 years for the group of patients who presented for postoperative follow-ups.

\section{Discussions}

The decision to perform cervical exenteration should be taken responsibly. It most frequently offers a palette of symptoms incompatible with quality of life. Tumour invasion of the structures of the cervical region may originate in the hypopharynx, the larynx, the cervical oesophagus, the thyroid or extracervical pathologies, extended into the cervical region. Strong stenosis or obstruction of the digestive tract and/or obstruction of the airway often requires tracheostomy and a gastro- or jejunostomy in order to recover the patient from the critical condition. We need a preoperative clinical, imaging and histopathological diagnosis as accurate as possible in reference to the starting point of the tumour invasion of the cervical region.Beyond the decision regarding the therapeutic sequence radiochemotherapy or surgery - the correct diagnosis of the primary organ affected by the malignancy leads to the lymph nodes groups that must be included in the lymphadenectomy. The surgical team should be prepared to continue cervical exenteration with transhiatal oesophagectomy if the extemporaneous anatomo-pathological examination indicates tumour cells on the tissue section and re-resection does not provide R0, especially in cancers of the hypopharynx extended to the oesophagus or in cervical oesophagus cancers.Resection of the left sternoclavicular joint allows for extension of the lower exeresis of the oesophagus, but is not always sufficient due to submucosal extension of the oesophageal cancer. Invasion on extemporaneous anatomopathological exam of the trachea stump requires re-resection and, sometimes, a mediastinal tracheostomy.

In this situation, resection of the trachea should be extended distally to include the retrosternal region, in order to obtain a minimum of $15 \mathrm{~mm}$ length of free tissue (4), otherwise the risk of recurrence at the level of the tracheal stump is high (5). Over the last decade cases of tracheal resections followed by tracheal reconstruction have also been reported, but these resections were performed in patients with oesophageal squamous cell carcinoma in a low number of cases, and most patients have subsequently developed tracheal stenosis (6).

In invasive tumours of the cervical region, the large vessels of the neck can be invaded by the tumour and/or altered by radiotherapy. Careful preoperative assessment is essential. If the tumour unilaterally invades the common carotid, causing stenosis or obstruction, and clinically the patient is not neurologically impaired, resection of the common carotid artery does not require reconstruction. It is important to preserve the bifurcation of the common carotid artery. If the artery is only stenotic, it is preferable to attempt dissecting it from the tumour, usually subadventitially. Vascular fragility may be induced by the effects of radiotherapy. Patients who have undergone cervical radiotherapy treatment require the adaptation of the vascular suture technique for free tissue transfers, due to the tendency towards detachment of the intima from the vascular wall, to avoid thrombosis of vascular microanastomoses and loss of tissue autotransplant. If needed, cervical vessels may be replaced by grafts. However, the risk of secondary haemorrhages in these cases is not at all negligible, given the risk of collection accumulation after exeresis and lymphadenectomy, and of their infection, or the risk of digestive fistula with impact on synthetic grafts.

Oesophageal cancer has a very severe prognosis, but healing chances are intimately related to the lymphatic extension of the tumour and to the possibility of complete removal of this 
locoregional extension (7). It has already been established that lymph node metastases of oesophageal squamous cancers can occur even in the early stages of the disease, a possibility being even that they only interest the lymph nodes located away from the primary tumour, the so-called "skip metastases" (8). There is a debate on the appropriate extension of lymphadenectomy so that it can improve prognosis without increasing morbidity. This is the reason why we perform a radical neck dissection as part of cervical exenteration, removing the paraoesophageal cervical lymph nodes, the central lymph nodes and the supraclavicular lymph nodes, a process adopted as a standard procedure initially in experienced surgical centres in Japan and, subsequently, by Western surgical centres $(9,10)$. Theoretically, if all the lymph nodes involved were completely removed together with the primary tumour, the chances of healing would be greatly increased. This is the conclusion of a study that included 2,303 patients from 9 international centres, which showed that the number of lymph nodes removed was an independent predictive factor for survival, and that in order to maximize this result, the exeresis of a minimum number of 23 lymph nodes is necessary (11). A similar conclusion was also provided by a 2010 study that included a double number of patients (12). However, when lymphadenectomy is associated with a rescue resection for tumour recurrence after radio-chemotherapy, as is the case with most patients undergoing cervical exenterations, it appears that the number of lymph nodes removed does not have a significant impact on survival, and extensive lymphadenectomy is associated with increased postoperative morbidity $(13,14)$.

Digestive reconstruction is difficult, especially in patients with secondary changes due to radiotherapy (15). The choice of the manner of reconstruction is not standardized. There are authors who prefer the use of pedicle locoregional flaps, while the majority are oriented towards microsurgical free transfers - jejunum, fasciocutaneous flaps - or stomach/colon. Each of the flaps or organs used for reconstruction present advantages and disadvantages $(16,17,18,19)$.
For cervical exenteresis, the use of isoperistaltic jejunum free transfer ensures the best results in our experience. Once the graft is included into the digestive tract, it will determine minimal complications compared to other digestive oesophagoplasty variants, such as the stomach or colon (20). In case of relapse after a free jejunal transfer, if reintervention is seen as a probability, the stomach or colon can be used for pharyngooesophageal reconstruction.

Postoperative imaging evaluations may indicate local relapse. This usually occurs at the level of anastomosis areas (21).

Survival depends on the primary tumour, the degree of differentiation, the lymphatic extension, and the degree of completion of primary exeresis and lymphadenectomy.

\section{Conclusions}

Cervical exenteration involves a rigorous selection of patients and a flexible surgical strategy adapted to the reality of the surgical field. Patients who can benefit from this type of intervention are those presenting cervical tumours with different starting points, but invasive in the digestive tract and/or airway, without distant metastases and/or recurrence after radiochemotherapy. The key elements of this intervention are en bloc resection of the tumour with radical lymphadenectomy, definitive tracheostomy and digestive reconstruction. In our experience, free jejunum transfer is the first option for restoring digestive continuity.

\section{References}

1. Madsen JC, Mathisen DJ, Grillo HC. Cervical exenteration. Semin Thorac Cardiovasc Surg. 1992;4(4):292-9.

2. Honings J1, Stephen AE, Marres HA, Gaissert HA. The management of thyroid carcinoma invading the larynx or trachea. Laryngoscope. 2010;120(4):682-9. doi: 10.1002/lary.20800.

3. Rice TW. Cancers of the upper aerodigestive tract: cervical exenteration In Sugarbaker D, Bueno R Colson Y, Jaklitsch M Krasna M, Mentzer S Adult Chest Surgery, 2nd ed. McGraw Hill Education; 2015.

4. Orringer MB, Sloan $\mathrm{H}$. Anterior mediastinal tracheostomy: indications, techniques, and clinical experience. J Thorac Cardiovasc Surg. 1979;78(6):850-9.

5. Esteban F, Moreno JA, Delgado-Rodriguez M, Mochom A. Risk factors involved in stomal recurrence following laryngectomy. Laryngol Otol. 1993;107(6):527-31.

6. Cordos I, Bolca C, Paleru C, Posea R, Stoica R. Sixty tracheal resections--single center experience. Interact Cardiovasc Thorac 
Surg. 2009;8(1):62-5; discussion 65. doi: 10.1510/icvts.2008 184747. Epub 2008 Oct 8.

7. Akiyama $\mathrm{H}$, Tsurumaru M, Udagawa $\mathrm{H}$, Kajiyama Y: Radical lymph node dissection for cancer of the thoracic esophagus. Ann Surg. 1994;220(3):364-72; discussion 372-3.

8. Kato $\mathrm{H}$, Tachimori $\mathrm{Y}$, Watanabe $\mathrm{H}$, lizuka T, Terui S, Itabashi M, et al. Lymph node metastasis in thoracic esophageal carcinoma. $J$ Surg Oncol. 1991;48(2):106-11.

9. Shimada H, Okazumi S, Matsubara H, Nabeya $Y$, Shiratori $T$, Shimizu T, et al. Impact of the number and extent of positive lymph nodes in 200 patients with thoracic esophageal squamous cell carcinoma after threefield lymph node dissection. World J Surg. 2006;30(8):1441-9.

10. Lerut T, Nafteux P, Moons J, Coosemans W, Decker G, De Leyn P, et al Three-field lymphadenectomy for carcinoma of the esophagus and gastroesophageal junction in 174 R0 resections: impact on staging, disease-free survival, outcome: a plea for adaptation of TNM classification in upper-half esophageal carcinoma. Ann Surg. 2004;240(6): 962-72; discussion 972-4.

11. Peyre CG, Hagen JA, DeMeester SR, Altorki NK, Ancona E, Griffin $S M$, et al. The number of lymph nodes removed predicts survival in esophageal cancer: an international study on the impact of extent of surgical resection. Ann Surg. 2008;248(4):549-56. doi: 10.1097/ SLA.0b013e318188c474.

12. Rizk NP, Ishwaran H, Rice TW, Chen LQ, Schipper PH, Kesler KA, et al. Optimum lymphadenectomy for esophageal cancer. Ann Surg. 2010;251(1):46-50. doi: 10.1097/SLA.0b013e3181b2f6ee.
13. Koen Talsma A, Shapiro J, Looman CW, van Hagen P, Steyerberg EW, van der Gaast A, et al. Lymph node retrieval during esophagectomy with and without neoadjuvant chemoradiotherapy. Prognostic and therapeutic impact on survival. Ann Surg. 2014:260(5):78692; discussion 792-3. doi: 10.1097/SLA.0000000000000965.

14. Darling G. The role of lymphadenectomy in esophageal cancer. J Surg Oncol. 2009;99(4):189-93. doi: 10.1002/jso.21209.

15. Yu P, Robb GL.Reconstruction of the hypopharynx and cervical esophagus. In Neligan PC, Wei F-C eds. Microsurgical reconstruction of the head and neck. St. Louis, Missouri: Quality Medical Publishing, Inc; 2010. p. 645-678.

16. Coleman JJ 3rd. Reconstruction of the pharynx and cervical esophagus. Semin Surg Oncol. 1995;11(3):208-20.

17. Miller JL, Lee RB. Free jejunal interposition of the esophagus. Semin Thorac Cardiovasc Surg. 1992:4(4):286-91.

18. Bakamjian VY. A ten stage method for pharyngoesophageal reconstruction of the cervical esophagus and pharynx. Plast Reconstr Surg 1965;36:509

19. Carlson GW, Schusterman MA, Guillamendegui OM. Total reconstruction of the hypopharynx and cervical esophagus: a 20-years experience. Ann Plast Surg. 1992;29(5):408-12.

20. Marks JL, Hofstetter WL. Esophageal reconstruction with alternative conduits. Surg Clin North Am. 2012;92(5):1287-97. doi: 10.1016/j.suc.2012.07.006. Epub 2012 Aug 20.

21. Schmalfuss I. Neoplasms of the Hypopharynx and Proximal Esophagus. In: Hermans R. (eds) Head and Neck Cancer Imaging. Medical Radiology. Berlin, Heidelberg: Springer; 2008. p 81-102. 